\title{
PENGEMBANGAN SISTEM BASISDATA ONGKOS LOGISTIK INDONESIA
}

\author{
Nova Indah Saragih \\ Program Studi Teknik Industri \\ Universitas Widyatama \\ Jl. Cikutra No. 204A Bandung \\ nova.indah@widyatama.ac.id
}

\begin{abstract}
Abstrak
Pengukuran ongkos logistik nasional merupakan indikator yang penting bagi sebuah negara untuk mendukung pembuatan kebijakan nasional, target operasional, dan modal sumber daya. Selain itu, pengukuran ongkos logistik nasional juga memberikan pengukuran performansi, membuka jalan kepada tindakan perbaikan, serta merupakan infrastruktur yang penting dalam pertumbuhan ekonomi. Indonesia telah memiliki model pengukuran ongkos logistik nasional yang disesuaikan dengan ketersediaan data di Indonesia. Data yang dibutuhkan untuk menghitung ongkos logistik Indonesia mencapai 600 data. Data tersebut akan dikumpulkan setiap tahun karena ongkos logistik nasional juga akan dihitung setiap tahunnya. Oleh karena itu, dibutuhkan sistem basisdata yang dapat mempermudah pengelolaan data yang digunakan untuk menghitung ongkos logistik Indonesia.
\end{abstract}

Kata kunci:

Basisdata, ongkos logistik Indonesia, sistem.

\begin{abstract}
National logistics cost measurement is an important indicator for a country to support national policy making, the targeted deployment of operational, and capital resources. Besides that, national logistics cost measurement is enable measurement of performance, pave the way for corrective actions, and an important infrastructure for economic growth. Indonesia already has its own national logistics cost model which is appropriated with the availability of the data in Indonesia. There are about 600 data that are needed to calculate Indonesia logistics cost. Those data will be collected
\end{abstract}

every year for national logistics cost also will be calculated every year. Therefore, it needs database system that can simplify the management of the data that are used to calculate Indonesia logistics cost.

Keywords:

Database, Indonesia logistics cost, system.

\section{Pendahuluan}

Pengukuran ongkos logistik nasional merupakan hal yang penting bagi sebuah negara karena merupakan sebuah indikator yang tepat untuk masa lalu dan masa depan sebuah negara. Sebagai indikator utama, pengukuran ongkos logistik nasional akan mendukung pembuatan kebijakan nasional dan target operasional serta modal sumber daya (investasi infrastruktur transportasi). Sebagai indikator pendukung, pengukuran ongkos logistik nasional akan memberikan pengukuran performansi dan membuka jalan kepada tindakan perbaikan. Pentingnya pengukuran ongkos logistik nasional semakin meningkat ketika diketahui pula bahwa efisiensi aktivitas logistik nasional merupakan infrastruktur yang penting dalam pertumbuhan ekonomi (Pishvaee dkk., 2009).

Setiap negara memiliki model pengukuran ongkos logistik nasional yang berbeda-beda yang disesuaikan dengan ketersediaan data di negaranya. Indonesia sendiri telah memiliki model pengukuran ongkos logistik nasional yang dikembangkan oleh Saragih dan Nur Bahagia (2011). Saragih dan Nur Bahagia (2011) mengembangkan model pengukuran ongkos logistik Indonesia yang terdiri dari tiga kategori ongkos yaitu ongkos transportasi, ongkos penanganan persediaan, dan ongkos administrasi. Masing-masing kategori ongkos tersebut dibagi-bagi 
kembali menjadi komponen ongkos, elemen ongkos, dan sub-elemen ongkos seperti yang dapat dilihat pada Tabel 1 .

Tabel 1. Kategori Ongkos Logistik Indonesia

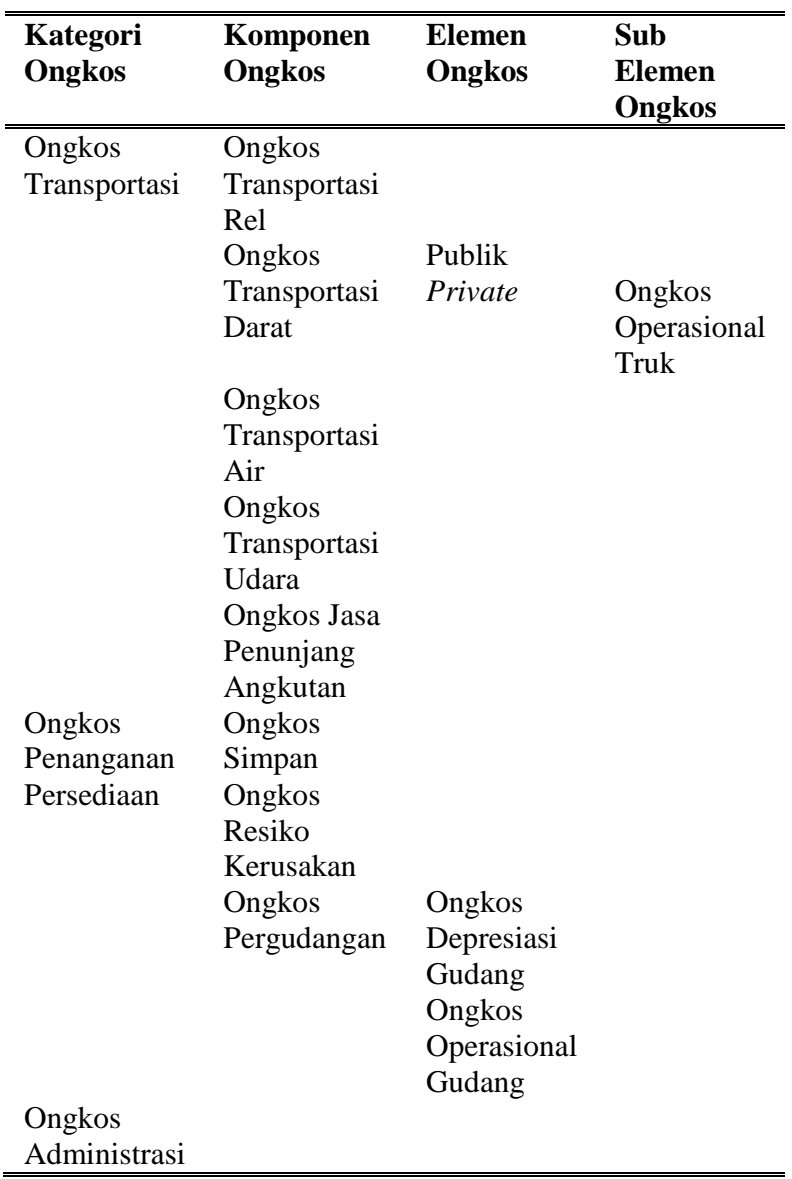

Setiap kategori ongkos memiliki sumber data yang berbeda-beda. Data yang dibutuhkan untuk menghitung ongkos logistik Indonesia mencapai sekitar 600 data (Saragih dan Nur Bahagia, 2011). Data tersebut akan dikumpulkan setiap tahun karena ongkos logistik nasional juga akan dihitung setiap tahunnya. Oleh karena itu dibutuhkan sebuah sistem basisdata untuk memudahkan pengelolaan data yang digunakan dalam pengukuran ongkos logistik Indonesia.

Basisdata bertujuan untuk mengatur data sehingga diperoleh kemudahan, kecepatan, dan ketepatan dalam pengambilan kembali (Kusrini, 2007). Sehingga, dengan dikembangkannya sistem basisdata ongkos logistik Indonesia diharapkan dapat memberikan manfaat dari sisi kecepatan dan kemudahan dalam pengambilan, pengelompokkan, dan pengurutan data ongkos logistik Indonesia. Selain itu, sistem basisdata ongkos logistik Indonesia juga diharapkan dapat memberikan manfaat dari sisi ketepatan karena adanya penerapan tipe data, domain data, keunikan data, hubungan antardata, dan lainlain. Kemudahan dalam pembuatan program aplikasi baru juga merupakan manfaat lain dari pengembangan sistem basisdata ongkos logistik Indonesia.

\section{KEBUTUHAN SISTEM}

Sebelum mengembangkan sistem basisdata ongkos logistik Indonesia, akan ditentukan terlebih dahulu kebutuhan sistem basisdatanya. Kebutuhan sistem basisdata ongkos logistik Indonesia diberikan dalam peta data berupa input, proses, dan ouput data yang digunakan. Kebutuhan sistem basisdata ongkos logistik Indonesia dapat dilihat pada Tabel 2.

Tabel 2. Peta Data Ongkos Logistik Indonesia (Berlanjut)

\begin{tabular}{|c|c|c|}
\hline Input & Proses & Output \\
\hline $\begin{array}{l}\text { Data pendapatan } \\
\text { PT. KAI (D1) }\end{array}$ & $\begin{array}{l}\text { Perhitungan } \\
\text { ongkos } \\
\text { transportasi rel } \\
(\mathrm{P} 1)\end{array}$ & $\begin{array}{l}\text { Data ongkos } \\
\text { transportasi rel } \\
\text { (D2) }\end{array}$ \\
\hline $\begin{array}{l}\text { Data pendapatan } \\
\text { BEI sektor } \\
\text { transportasi darat } \\
\text { (D3) }\end{array}$ & $\begin{array}{l}\text { Perhitungan } \\
\text { ongkos } \\
\text { transportasi darat } \\
\text { publik (P2) }\end{array}$ & $\begin{array}{l}\text { Data ongkos } \\
\text { transportasi darat } \\
\text { publik (D4) }\end{array}$ \\
\hline $\begin{array}{l}\text { Data pendapatan } \\
\text { BEI sektor } \\
\text { transportasi air } \\
\text { (D5) }\end{array}$ & $\begin{array}{l}\text { Perhitungan } \\
\text { ongkos } \\
\text { transportasi air } \\
\text { (P3) }\end{array}$ & $\begin{array}{l}\text { Data ongkos } \\
\text { transportasi air } \\
\text { (D6) }\end{array}$ \\
\hline $\begin{array}{l}\text { Data pendapatan } \\
\text { BEI sektor } \\
\text { transportasi udara } \\
\text { (D7) }\end{array}$ & $\begin{array}{l}\text { Perhitungan } \\
\text { ongkos } \\
\text { transportasi udara } \\
\text { (P4) }\end{array}$ & $\begin{array}{l}\text { Data ongkos } \\
\text { transportasi udara } \\
\text { (D8) }\end{array}$ \\
\hline $\begin{array}{l}\text { Data pendapatan } \\
\text { BEI sektor jasa } \\
\text { transportasi (D9) }\end{array}$ & $\begin{array}{l}\text { Perhitungan } \\
\text { ongkos jasa } \\
\text { transportasi (P5) }\end{array}$ & $\begin{array}{l}\text { Data ongkos jasa } \\
\text { transportasi } \\
\text { (D10) }\end{array}$ \\
\hline $\begin{array}{l}\text { Data nilai tukar } \\
\text { rupiah (D11) }\end{array}$ & $\begin{array}{l}\text { Perhitungan } \\
\text { ongkos } \\
\text { transportasi darat } \\
\text { private }(\mathrm{P} 6)\end{array}$ & $\begin{array}{l}\text { Data ongkos } \\
\text { transportasi darat } \\
\text { private (D12) }\end{array}$ \\
\hline $\begin{array}{l}\text { Data ongkos } \\
\text { operasional truk } \\
\text { (D13) }\end{array}$ & $\begin{array}{l}\text { Perhitungan } \\
\text { ongkos } \\
\text { transportasi darat } \\
\text { private }(\mathrm{P} 6)\end{array}$ & $\begin{array}{l}\text { Data ongkos } \\
\text { transportasi darat } \\
\text { private (D12) }\end{array}$ \\
\hline $\begin{array}{l}\text { Data jarak } \\
\text { tempuh truk } \\
\text { (D14) }\end{array}$ & $\begin{array}{l}\text { Perhitungan } \\
\text { ongkos } \\
\text { transportasi darat }\end{array}$ & $\begin{array}{l}\text { Data ongkos } \\
\text { transportasi darat } \\
\text { private (D12) }\end{array}$ \\
\hline
\end{tabular}




\begin{tabular}{|c|c|c|}
\hline $\begin{array}{l}\text { Input } \\
\end{array}$ & Proses & Output \\
\hline $\begin{array}{l}\text { Data jumlah truk } \\
\text { (D15) }\end{array}$ & $\begin{array}{l}\text { private (P6) } \\
\text { Perhitungan } \\
\text { ongkos } \\
\text { transportasi darat } \\
\text { private (P6) }\end{array}$ & $\begin{array}{l}\text { Data ongkos } \\
\text { transportasi darat } \\
\text { private (D12) }\end{array}$ \\
\hline $\begin{array}{l}\text { Data aset } \\
\text { persediaan ketiga } \\
\text { sektor BEI (D16) }\end{array}$ & $\begin{array}{l}\text { Perhitungan } \\
\text { ongkos simpan } \\
\text { (P7) }\end{array}$ & $\begin{array}{l}\text { Data ongkos } \\
\text { simpan (D17) }\end{array}$ \\
\hline $\begin{array}{l}\text { Data tingkat suku } \\
\text { bunga pinjam } \\
\text { (D18) }\end{array}$ & $\begin{array}{l}\text { Perhitungan } \\
\text { ongkos simpan } \\
\text { (P7) }\end{array}$ & $\begin{array}{l}\text { Data ongkos } \\
\text { simpan (D17) }\end{array}$ \\
\hline $\begin{array}{l}\text { Data aset } \\
\text { persediaan ketiga } \\
\text { sektor BEI (D16) }\end{array}$ & $\begin{array}{l}\text { Perhitungan } \\
\text { ongkos resiko } \\
\text { kerusakan (P8) }\end{array}$ & $\begin{array}{l}\text { Data ongkos } \\
\text { resiko kerusakan } \\
\text { (D19) }\end{array}$ \\
\hline $\begin{array}{l}\text { Data aset tetap } \\
\text { ketiga sektor BEI } \\
\text { (D20) }\end{array}$ & $\begin{array}{l}\text { Perhitungan } \\
\text { ongkos depresiasi } \\
\text { (P9) }\end{array}$ & $\begin{array}{l}\text { Data ongkos } \\
\text { depresiasi } \\
\text { gudang (D21) }\end{array}$ \\
\hline $\begin{array}{l}\text { Data aset } \\
\text { persediaan ketiga } \\
\text { sektor BEI (D16) }\end{array}$ & $\begin{array}{l}\text { Perhitungan } \\
\text { ongkos } \\
\text { operasional } \\
\text { gudang (P10) }\end{array}$ & $\begin{array}{l}\text { Data ongkos } \\
\text { operasional } \\
\text { gudang (D22) }\end{array}$ \\
\hline
\end{tabular}

Dari Tabel 2 dapat diketahui bahwa terdapat 22 jenis data yang dibutuhkan untuk menghitung ongkos logistik Indonesia. Selain itu, dibutuhkan sebanyak 10 proses perhitungan untuk menghasilkan ongkos logistik Indonesia.

\section{III.METODOLOGI}

Penelitian ini menggunakan pendekatan Fadlil dkk. (2008) untuk mengembangkan sistem basisdata yang bagan alirnya dapat dilihat pada Gambar 1 . Tahap pertama dalam mengembangkan sistem basisdata ongkos logistik Indonesia adalah dengan membuat bagan berjenjangnya. Bagan berjenjang menunjukkan dekomposisi fungsional atas-bawah dan struktur dari sistem basisdata. Diagram berjenjang merupakan alat perencanaan yang sangat penting untuk proses model yang lebih terperinci, yang dikenal dengan data flow diagram (Whitten dan Bentley, 2007). Sesuai dengan namanya, bagan berjenjang menunjukkan hirarki dari sistem, mulai dari level atas sampai dengan level bawah.

Tahap kedua adalah membuat diagram konteks ongkos logistik Indonesia yang menunjukkan level atas dari hirarki sistem. Jika level diberi nomor, maka level atas diberi nomor 0 dan level bawah untuk nomor selanjutnya (level 1 , level 2 , dan seterusnya). Diagram konteks merupakan level 0. Level 1, level 2, dan seterusnya yang dikenal dengan data flow diagram atau DFD.

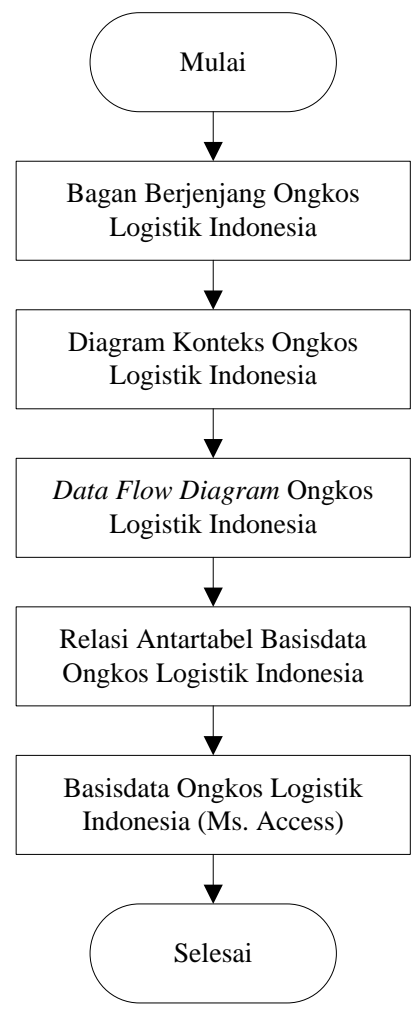

Gambar 1. Bagan Alir Penelitian

Tahap ketiga adalah membuat data flow diagram ongkos logistik Indonesia yang selanjutnya disebut DFD. DFD adalah representasi grafis yang menggambarkan aliran informasi dan transformasi yang diterapkan ketika data bergerak dari input ke output (Pressman, 2001). Tahap keempat adalah membuat peta data input proses output ongkos logistik Indonesia, tahap kelima adalah membuat relasi antartabel ongkos logistik Indonesia, dan tahap keenam atau tahap terakhir adalah membuat basisdata ongkos logistik Indonesia, yang dalam penelitian ini menggunakan perangkat lunak Ms. Access.

\section{Hasil dan Pembahasan}

\section{IV.1 Bagan Berjenjang Ongkos Logistik Indonesia}

Bagan berjenjang ongkos logistik Indonesia dapat dilihat pada Gambar 2. Dapat dilihat pada Gambar 2 bahwa terdapat empat level ongkos logistik Indonesia, yang mana ongkos logistik Indonesia

Nova Indah Saragih 
sendiri merupakan level 0, kategori ongkos logistik Indonesia merupakan level 1, komponen ongkos logistik Indonesia merupakan level 2, elemen ongkos logistik Indonesia merupakan level 3, dan sub-elemen ongkos logistik Indonesia merupakan level 4.

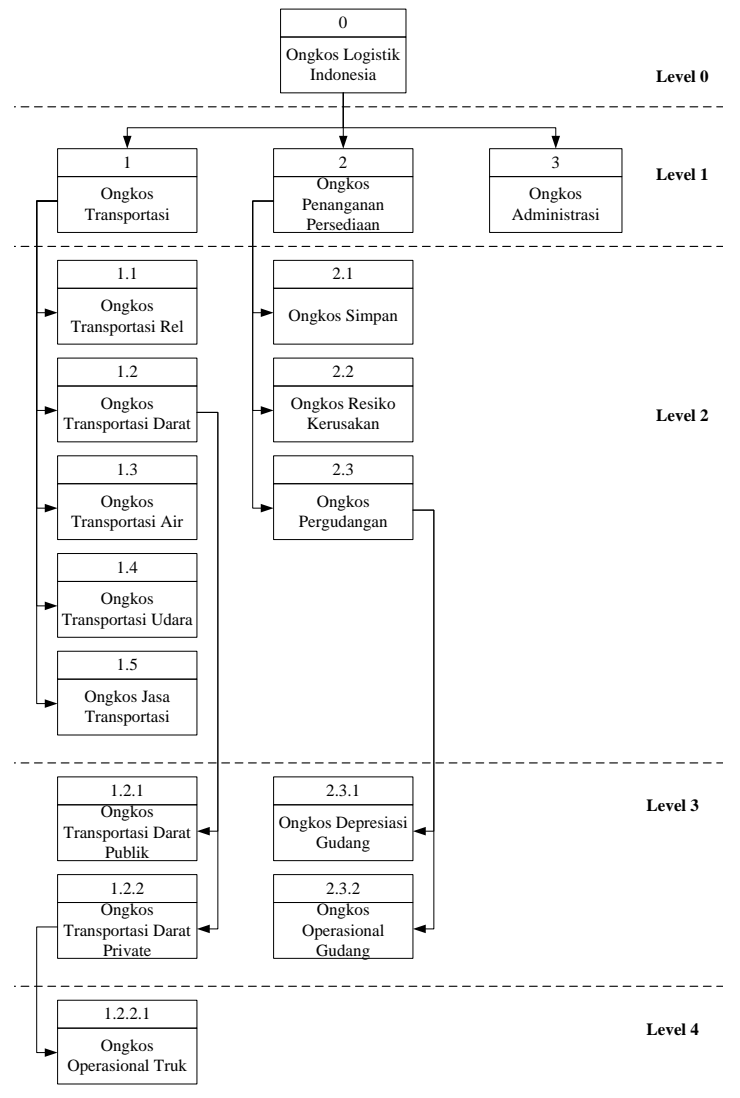

Gambar 2. Bagan Berjenjang Ongkos Logistik Indonesia

\section{IV.2 Diagram Konteks Ongkos Logistik Indonesia}

Diagram konteks terletak pada level atas dari hirarki (Pressman, 2001) atau level 0 dari diagram berjenjang. Diagram konteks ongkos logistik Indonesia dapat dilihat pada Gambar 3. Dari Gambar 3 dapat diketahui bahwa terdapat 6 (enam) sumber data yang dibutuhkan untuk menghitung ongkos logistik Indonesia, yaitu BEI (Bursa Efek Indonesia), BPS (Badan Pusat Statistik), BI (Bank Indonesia), PT. KAI (Kereta Api Indonesia), Hubdat (Departemen Perhubungan Darat), dan The Asia Foundation.

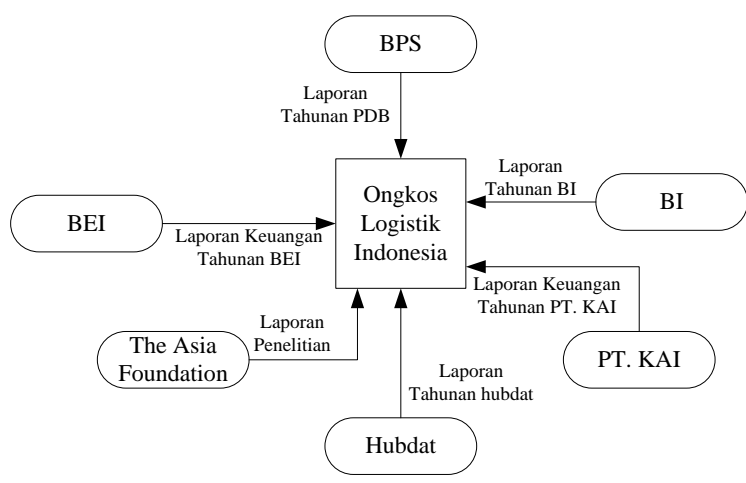

Gambar 3. Diagram Konteks Ongkos Logistik Indonesia

\section{IV.3 DFD Ongkos Logistik Indonesia}

DFD level 1 ongkos logistik Indonesia untuk kategori ongkos transportasi dapat dilihat pada Gambar 4. Sama halnya dengan diagram konteks pada, untuk DFD level 1 pada kategori ongkos transportasi terdapat 6 (enam) sumber data yaitu BEI, BPS, BI, PT. KAI, Hubdat, dan The Asia Foundation.

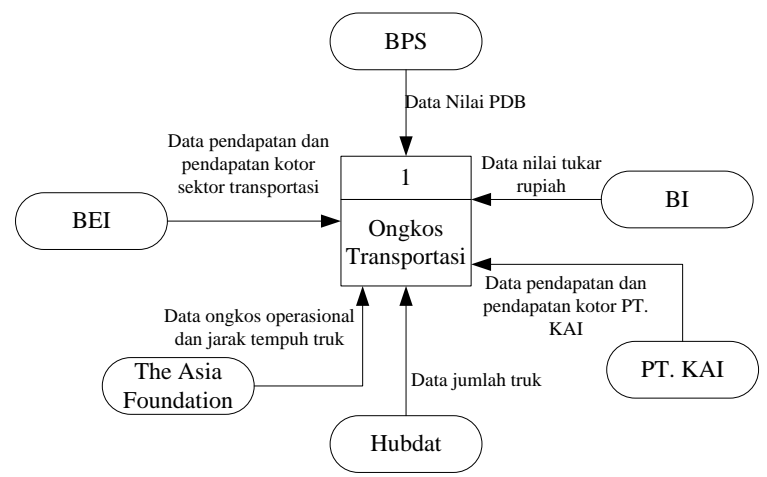

Gambar 4. DFD Level 1 (Ongkos Transportasi)

DFD level 1 ongkos logistik Indonesia untuk kategori ongkos penanganan persediaan dapat dilihat pada Gambar 5. 


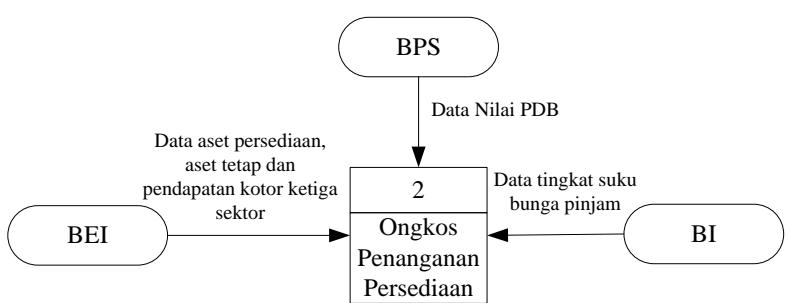

\section{Gambar 5. DFD Level 1 (Ongkos Penanganan Persediaan)}

Terdapat 3 (tiga) sumber data yang dibutuhkan untuk menghitung ongkos penanganan persediaan, yaitu BEI, BPS, dan BI. Jenis-jenis data yang diberikan oleh setiap sumber data dapat dilihat secara lengkap di Gambar 5.

DFD level 2 ongkos logistik Indonesia untuk kategori ongkos transportasi dapat dilihat pada Gambar 6.

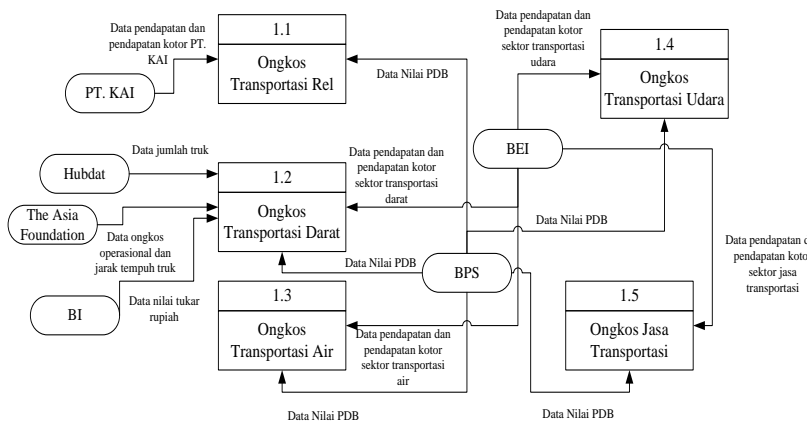

Gambar 6. DFD Level 2 (Ongkos Transportasi)

Pada level 2 untuk kategori ongkos transportasi, terdapat 5 (lima) komponen ongkos, yaitu ongkos transportasi rel, ongkos transportasi darat, ongkos transportasi air, ongkos transportasi udara, dan ongkos jasa penunjang angkutan.

DFD level 2 ongkos logistik Indonesia untuk kategori ongkos penanganan persediaan dapat dilihat pada Gambar 7.

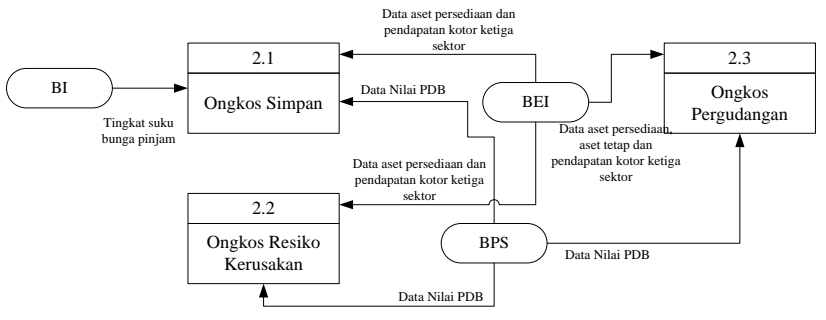

\section{Gambar 7. DFD Level 2 (Ongkos Penanganan Persediaan)}

Pada level 2 untuk kategori ongkos penanganan persediaan, terdapat 3 (tiga) komponen ongkos, yaitu ongkos simpan, ongkos resiko kerusakan, dan ongkos pergudangan.

DFD level 3 ongkos logistik Indonesia untuk komponen ongkos transportasi darat dapat dilihat pada Gambar 8.

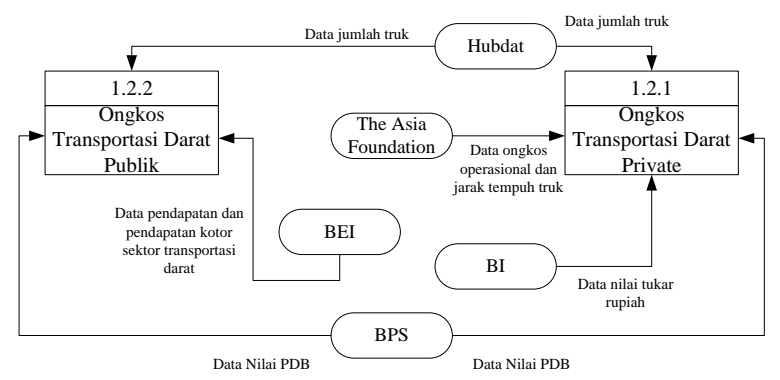

\section{Gambar 8. DFD Level 3 (Ongkos Transportasi} Darat)

Pada level 3, terdapat 2 (dua) elemen ongkos untuk komponen ongkos transportasi darat, yaitu ongkos transportasi darat publik dan ongkos transportasi darat private.

DFD level 3 ongkos logistik Indonesia untuk komponen ongkos pergudangan dapat dilihat pada Gambar 9. 


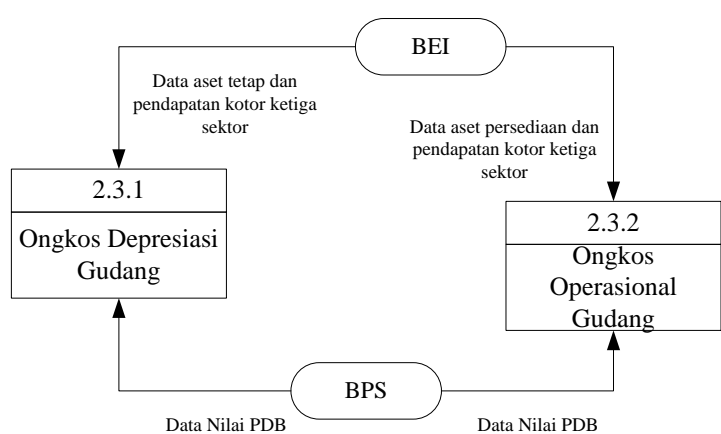

Gambar 9. DFD Level 3 (Ongkos Pergudangan)

Pada level 3 untuk komponen ongkos pergudangan, terdapat 2 (dua) elemen ongkos, yaitu ongkos depresiasi gudang dan ongkos operasional gudang.

\section{IV.4 Relasi Antartabel Ongkos Logistik Indonesia}

Relasi antartabel ongkos logistik Indonesia dapat dilihat pada Gambar 10.

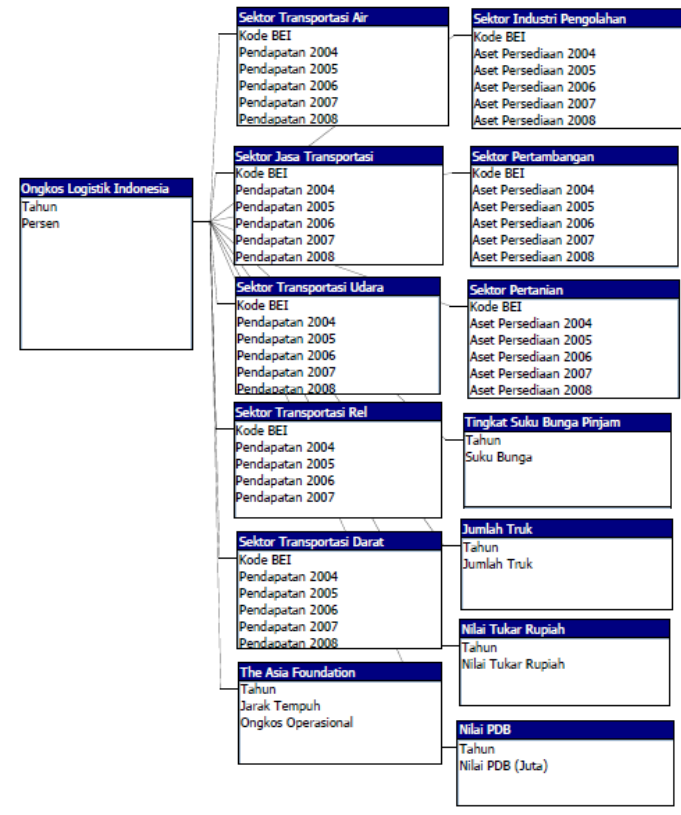

Gambar 10. Relasi Antartabel Ongkos Logistik Indonesia Dengan Sektor Transportasi

Dari Gambar 10 dapat diketahui bahwa perhitungan satu tahun ongkos logistik Indonesia membutuhkan banyak data, sehingga semua relasinya adalah one to many.

\section{IV.5 Basisdata Ongkos Logistik Indonesia}

Perangkat lunak yang digunakan untuk mengembangkan basisdata dalam penelitian ini adalah Ms. Access. Penggunaan Ms. Access dilatarbelakangi oleh kemudahan penggunaannya. Tampilan Ms. Access untuk basisdata ongkos logistik Indonesia dapat dilihat pada Gambar 11.

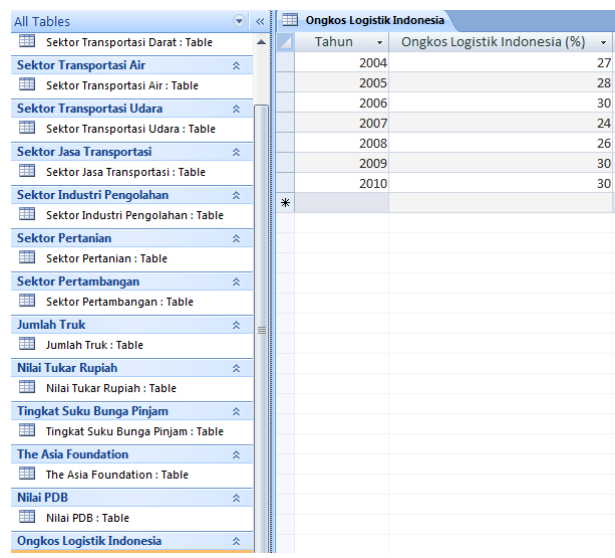

Gambar 11. Tampilan Ms. Access Basisdata Ongkos Logistik Indonesia

\section{KESIMPUlan DAN SARAN}

Penelitian ini mengembangkan sistem basisdata ongkos logistik Indonesia untuk memudahkan pengelolaan data yang digunakan untuk menghitung ongkos logistik Indonesia setiap tahunnya. Dibutuhkan sekitar 600 data yang terbagi menjadi 22 jenis data untuk menghitung ongkos logistik Indonesia. Sumber-sumber data tersebut yaitu BEI, BPS, BI, PT. KAI, Hubdat dan The Asia Foundation. Sistem basisdata ongkos logistik Indonesia memberikan kemudahan, kecepatan, dan ketepatan pengelolaan data yang digunakan.

Penelitian ini juga membuka peluang untuk penelitian selanjutnya berkaitan dengan pengembangan sistem basisdata ongkos logistik Indonesia yang mana semua sumber data seperti BEI, BPS, BI, dan lain-lain, dapat memberikan data yang dibutuhkan secara online setiap tahunnya ke dalam sistem basisdata tersebut sehingga menghilangkan aktivitas entry data secara manual dan menghindari terjadinya error.
Nova Indah Saragih

Jurnal Ilmiah Teknologi Informasi Terapan

Volume III, No 1, 15 Desember 2016 


\section{REFERENSI}

Pishvaee, M.S., Basiri, H., dan Sajadieh, M.S. (2009). Supply Chain and Logistics in National, International and Governmental Environment (Concepts and Models). Springer-Verlag Berlin Heidelberg.

Saragih, N.I. dan Nur Bahagia, S. (2011). Pengembangan Model Pengukuran Ongkos Logistik Indonesia. Tesis Teknik dan Manajemen Industri. Institut Teknologi Bandung.

Kusrini (2007). Strategi Perancangan dan Pengelolaan Basis Data. Andi Offset. Yogyakarta.

Fadlil, A., Firdausy, K., dan Hermawan, F. (2008). Pengembangan Sistem Basis Data Presensi Perkuliahan Dengan Kartu Mahasiswa BerBarcode. Telkomnika, vol. 6, no. 1, hal. 65 72.

Whitten, J.L. dan Bentley, L.D. (2007). System Analysis And Design Methods. Seventh Edition. McGraw-Hill/Irwin.

Pressman, R.S. (2001). Software Engineering: A Practitioner's Approach. Fifth Edition. McGraw-Hill. 